Reprod. Nutr. Dévelop., 1983, 23 (1), 51-63.

\title{
Effects of long-term ad libitum feeding on plasma lipid components and blood glucose, $\beta$-hydroxybutyrate and insu- lin concentrations in lean adult sheep
}

\author{
Françoise VANDERMEERSCHEN-DOIZÉ, J.-C. BOUCHAT, Marie-Antoinette \\ BOUCKOMS-VANDERMEIR, R. PAQUAY
}

\begin{abstract}
Laboratoire de Physiologie animale, Facultés Universitaires de Namur rue de Bruxelles 61, B-5000 Namur, Belgium
\end{abstract}

Summary. The long-term changes in plasma lipid composition and blood glucose, $\beta$ hydroxybutyrate and insulin concentrations in experimental ad libitum fed adult Suffolk sheep were studied and compared with those of control sheep receiving a maintenance diet. The results were interpreted in relation to changes in food intake, body weight and body composition. state.

Plasma lipid distribution was slightly influenced by the intake level and the fattening

Compared to the maintenance diet, ad libitum feeding induced a decrease in the concentration of plasma free fatty acids (FFA) ; when the food intake decreased, this FFA concentration increased gradually.

The fatty acid composition of the lipid fractions was subject to variation in the longterm ad libitum fed sheep. Myristic and palmitic acids in FFA, palmitoleic acid in triglycerides and linoleic acid in all the lipid fractions showed decreasing values associated with reduced food intake in the fattening sheep. Stearic and oleic acids in FFA, phospholipids and cholesterol esters increased when body weight and body fat increased and food intake decreased ; they showed stable values by the end of the experiment, when food intake and body weight and composition also stabilized.

Throughout the test, blood glucose concentration remained unaffected. A stable blood $\beta$-hydroxybutyrate concentration, 2 times the control level, was observed from the 4th to the 10th experimental week in the ad libitum fed sheep (phase 1). From the 14th to the 26th experimental week (phase 2), decreased values were associated with increasing body weight and decreasing food intake. From the 30th week on (phase 3), $\beta$ hydroxybutyrate concentration stabilized at a level 50 p. 100 higher than in the control sheep.

During the first 6 weeks of ad libitum feeding, the experimental sheep achieved the same plasma insulin concentration as the control sheep. Thereafter a 30-fold increase was noted. Moreover, fluctuations of between 20 and $1600 \mu \mathrm{U} / \mathrm{ml}$ were observed in fattening phases 2 and 3.

This experiment demonstrated that feeding adult sheep ad libitum induces complex interrelationships between food intake and fattening state on the one hand and several blood substances on the other. Other experiments are needed to clarify these interrelationships.

\section{Introduction.}

In a previous paper (Vandermeerschen-Doizé et al., 1982), it was found that voluntary food intake in mature Suffolk sheep was closely related to body weight 
and body fat. Mature lean sheep reached a stable body weight after several months of ad libitum feeding. This body weight remained remarkably constant and was associated with stable body fat content, adipose tissue morphology and low food intake.

These observations raised a question as to the existence of signals, transmitted via the circulation, to inform the central nervous system (particularly the hypothalamic ventromedial and lateral control system) of the amount of body fat reserves. Indeed, since the lipostatic theory of food intake control suggested by Kennedy (1950), no study has clarified the nature of the circulating metabolites related to the amount of body fat and determining the long-term feeding behaviour of animals.

In order to orient our tests to discover these metabolites in adult sheep fed ad libitum over long periods of time, we thought it would be interesting to determine the changes in some blood factors as well as in food intake and body composition in these sheep.

The present paper studies the profiles obtained for the different blood lipid constituents (plasma lipid distribution, FFA concentration, fatty acid composition of the different plasma lipids), glucose, $\beta$-hydroxybutyrate and insulin content ; results relating to food intake, body weight, body composition and adipocyte morphology have already been reported (Vandermeerschen-Doizé et al., 1982).

\section{Material and methods.}

The experimental design has been described previously (VandermeerschenDoizé et al., 1982). During a pre-experimental period, 11 adult Suffolk ewes, housed in individual cages, received a maintenance diet composed of $300 \mathrm{~g}$ of hay and $500 \mathrm{~g}$ of a commercial mixture. Thereafter, they were divided into two groups. Three control sheep were fed a maintenance diet for 9 months and 8 experimental sheep received hay and concentrates ad libitum.

Food intake and body weight were measured and blood samples were taken every week ; body composition and fat biopsies were carried out every 4 weeks.

The blood lipids were analyzed according to a modified method of Christophe and Matthijs (1966). Plasma was extracted with ethanol-ether (3:1) and then filtered, supplemented with chloroform and concentrated before adding hepta-decanoic acid as the internal standard (the plasma of sheep usually contains only undetectable amounts of odd-chain fatty acids). The solution was evaporated to dryness under $\mathrm{N}_{2}$. The residue was dissolved in chloroformmethanol, spotted on a silica gel $\mathrm{H} 60$ plate " pinked " by incorporation of Rhodamine $6 \mathrm{G}$ and developed with petroleum ether-acetone (85:15) and then hexane. The phospholipids, FFA, free cholesterol, triglycerides and cholesteryl esters thus separated were measured by fluorescence quenching with a Vitatron TDL-100 densitometer. This procedure authorized qualitative estimation of the total blood lipids.

After densitometric reading, the bands were scraped off and methylation was achieved with benzine-methanol-sulfuric acid (100-200-10). The samples were extracted twice with petroleum-ether, washed with $\mathrm{Na}_{2} \mathrm{CO}_{3} 10$ p. 100 and 
water, dried with anhydrous $\mathrm{Na}_{2} \mathrm{SO}_{4}$ and evaporated to dryness under $\mathrm{N}_{2} . \mathrm{N}$ heptane was added and the samples were injected on a 5 p. 100 polymer EGSS$X$ column in a Hewlett-Packard 5840A gas chromatograph. An integrator, coupled with the chromatograph directly expressed the plasma FFA concentration in $\mathrm{mg} / 100 \mathrm{ml}$ of plasma and the fatty acid composition of the lipid fractions in p. 100.

The technique for determining blood glucose and ketone bodies has been described in a previous paper (Doizé et al., 1979).

Insulin was assayed by a double antibody radioimmunoassay technique using ovine insulin as the standard and iodinated ovine insulin as the competitive binder (Morgan and Lazarow, 1963). Human insulin antibody and a second antibody (goat anti-guinea pig gamma globulin) were purchased from AHS.

\section{Results.}

As explained in our previous paper (Vandermeerschen-Doizé et al., 1982), the changes observed during the fattening of lean sheep could be divided into three different phases: phase 1 (from the 4th to 10th week), phase 2 (from the 14th to 26th week) and phase 3 (from the 30th week to the end of the experiment). Phase 1 was preceded by a 6 -week prephase, and there were a few weeks of transition between phases 1 and 2 and phases 2 and 3 .

Plasma lipid distribution. - Throughout the experiment, the control and the experimental groups had comparable mean (mean \pm SD) plasma contents (p. 100 of total plasma lipids) of FFA (control : $16.09 \pm 1.50$; experimental : $14.47 \pm 0.98$ ) and triglycerides (control : $13.43 \pm 1.41$; experimental : $11.41 \pm 1.35)$

Large fluctuations which progressively diminished during phases 2 and 3 were observed for all sheep during the prephase and phase 1.

During the experimental period, the mean content (p. 100 of total plasma lipids) of cholesteryl ester (control : $29.44 \pm 3.04$; experimental : $29.90 \pm 3.30$ ), cholesterol (control : $11.92 \pm 1.64$; experimental : $12.92 \pm 1.51$ ) and phospholipids (control : $28.60 \pm 1.23$; experimental : $31.12 \pm 1.44$ ) remained unchanged for both groups of animals. When taking the individual values for $a d$ libitum fed sheep into account, some animals showed a higher cholesterol content and, inversely, a lower cholesteryl ester content.

Plasma FFA concentration. - For both groups of sheep, when passing from the pre-experimental to the experimental diet of different composition, the plasma FFA concentration was greatly reduced. After this initial decrease the control sheep had a mean value of $119.7 \pm 21.3 \mathrm{mg} / \mathrm{l}$ of plasma throughout the experiment.

Figure 1 shows the changes in plasma FFA concentration of the experimental sheep. After the initial decrease, ad libitum fed animals had a lower FFA concentration ( $41.4 \pm 6.3 \mathrm{mg} / \mathrm{l}$ of plasma) than control sheep. A gradual increase was observed during the remaining two phases (phase $2: 54.7 \pm 16.4 \mathrm{mg} / 1$ plasma ; phase $3: 76.4 \pm 16.6 \mathrm{mg} / /$ plasma), although they failed to attain the concentration of control sheep by the end of the experiment. 


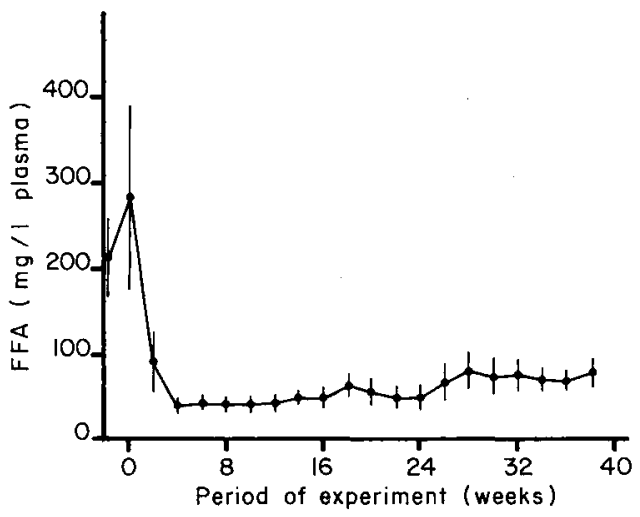

FIG. 1. - Free fatty acid concentration in ad libitum fed sheep. Weeks -2 to 0 correspond to the pre-experimental period and weeks 1-38 to the experimental period.

Fatty acid composition of the lipid fractions. - During the preexperimental period the fatty acid composition of the lipid fractions was identical in the control and the experimental sheep.

During the first weeks of the experimental period, large fluctuations in the fatty acid composition were observed in the control sheep ; these fluctuations then stabilized until the end of the experiment.

$A d$ libitum feeding of the experimental sheep induced the initial fluctuations. Thereafter clear changes were observed in the profiles of many acids.

1. Fatty acid composition of the FFA. During the experimental period, the mean values for the fatty acid composition of FFA in the control sheep were : $\mathrm{C} 14: 0,1.71 \pm 0.39 ; \mathrm{C} 16: 0,22.12 \pm 2.42 ; \mathrm{C} 16: 1,3.52 \pm 0.87 ; \mathrm{C} 18: 0$, $32.11 \pm 3.59 ; \mathrm{C} 18: 1,36.45 \pm 3.46 ; \mathrm{C} 18: 2,4.08 \pm 1.21)$.

In the experimental sheep, divergent changes were found during the experimental period.

Myristic and palmitic (fig. 2) acids were related and showed a similar change : ad libitum feeding induced an increase which reached a maximum during phase $1(\mathrm{C} 14: 0,3.09 \pm 0.45 ; \mathrm{C} 16: 0,31.18 \pm 2.48 \mathrm{p} .100$ of total FA) followed by a slow decrease in phase 2 (C14:0, 2.48 \pm 0.80, C16:0, $29.52 \pm 3.49$ p. 100 of total FA) and a faster decrease in phase 3 (C14:0, $2.15 \pm 0.56 ; C 16: 0,24.87 \pm 2.62$ p. 100 of total FA).

C16:1 content remained stable throughout the experiment $(3.26 \pm 1.57$ p. 100 of total FA).

Changes in stearic acid (fig. 3) were opposite to those of myristic and palmitic acids with the following mean $\pm S E$ values (p. 100 of total $F A$ ): $25.55 \pm 4.02$ in phase $1 ; 28.30 \pm 4.95$ in phase $2 ; 34.96 \pm 4.25$ in phase 3.

Results for oleic and linoleic acids are shown in figures 4 and 5 . The changes in C18:1 were opposite to those of C18:2. The lowest C18:1 values (p. 100 of total FA) were reached during phase 1 (26.49 \pm 4.72$)$, a gradual increase occurred in phase $2(29.00 \pm 4.29)$, approximating the control values in phase 3 


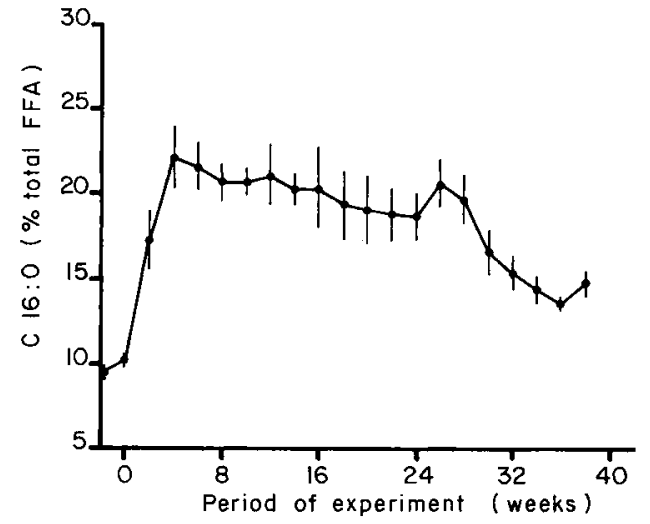

FIG. 2.

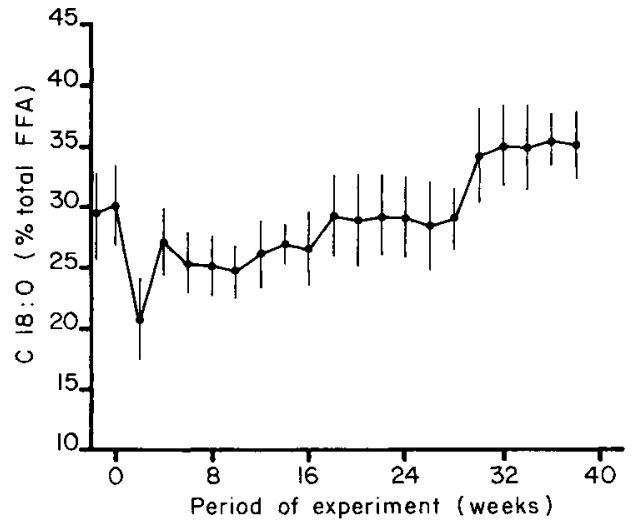

FIG. 3.

FIG. 2. - Changes in palmitic acid of plasma FFA in ad libitum fed sheep. Weeks -2 to 0 correspond to the pre-experimental period and weeks 1-38 to the experimental period.

FIG. 3. - Changes in stearic acid of plasma FFA in ad libitum fed sheep. Weeks -2 to 0 correspond to the pre-experimental period and weeks 1-38 to the experimental period.

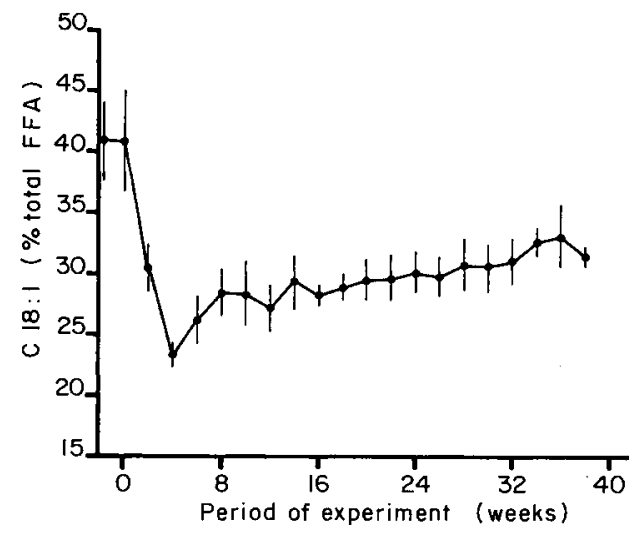

FIG. 4.

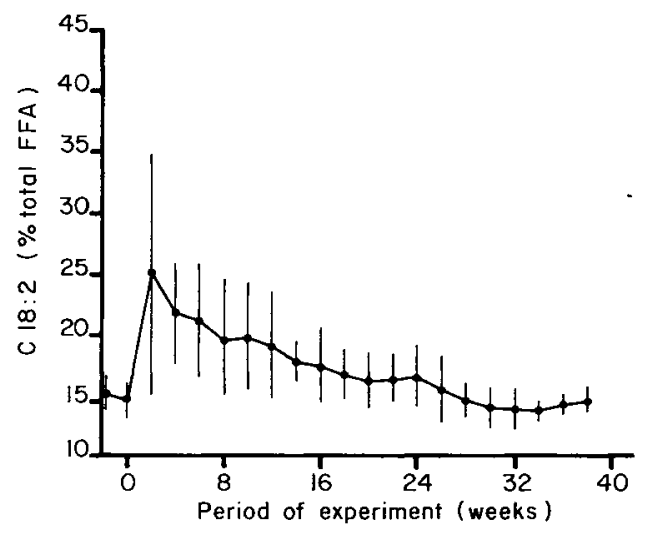

FIG. 5 .

FIG. 4. - Changes in oleic acid of plasma FFA in ad libitum fed sheep. Weeks -2 to 0 correspond to the pre-experimental period and weeks 1-38 to the experimental period.

FIG. 5. - Changes in linoleic acid of plasma FFA in ad libitum fed sheep. Weeks -2 to 0 correspond to the pre-exoperimental period and weeks 1-38 to the experimental period.

$(31.78 \pm 3.19)$. C18:2 values (p. 100 of total FA) decreased: phase 1: $10.48 \pm 4.52$, phase $2: 6.49 \pm 2.83$, phase $3: 3.90 \pm 1.40$. A stabilization was observed at the end of the experiment.

2. Fatty acid composition of the phospholipids. - The results obtained for the fatty acid composition of phospholipids in the control group were : C14:0, 


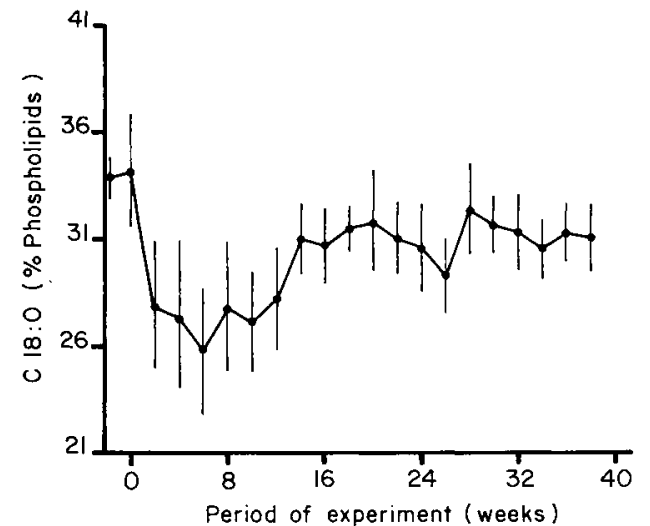

FIG. 6 .

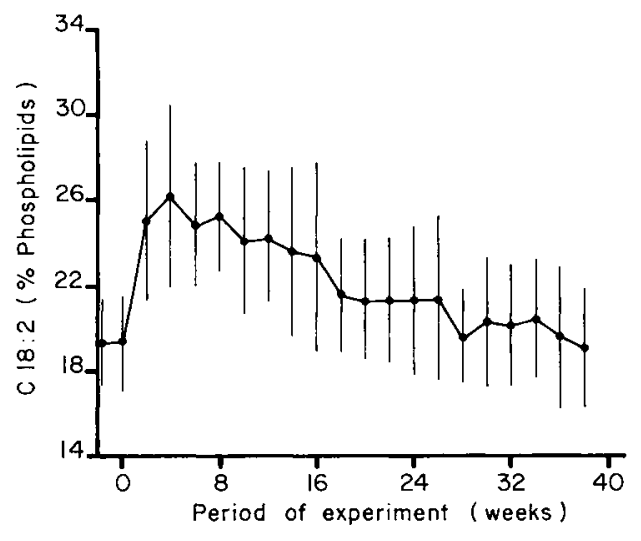

FIG. 7 .

FIG. 6. - Changes in stearic acid of plasma phospholipids in ad libitum fed sheep. Weeks -2 to 0 correspond to the pre-experimental period and weeks 1-38 to the experimental period.

FIG. 7. - Changes in linoleic acid of plasma phospholipids in ad libitum fed sheep. Weeks -2 to 0 correspond to the pre-experimental period and weeks 1-38 to the experimental period.

$0.45 \pm 0.13 ; \mathrm{C} 16: 0,22.75 \pm 1.46 ; \mathrm{C} 16: 1,2.63 \pm 0.82 ; \mathrm{C} 18: 0,31.81 \pm 1.67 ;$ $\mathrm{C} 18: 1,19.36 \pm 1.25 ; \mathrm{C} 18: 2,20.15 \pm 1.24 ; \mathrm{C} 18: 3,2.80 \pm 0.82$.

During the experimental period values (p. 100 of total FA) for myristic $(0.32 \pm 0.15)$, palmitic $(23.38 \pm 1.64)$, palmitoleic $(1.87 \pm 0.68)$ and linolenic acids $(2.72 \pm 0.97)$ in the experimental sheep were not modified.

Stearic (fig. 6) and oleic acids were related: low values (p. 100 of total FA) during phase 1 (C18:0, $26.06 \pm 5.48 ; C 18: 1,18.54 \pm 1.80)$ and increasing values in phases $2(\mathrm{C} 18.0,30.79 \pm 1.03 ; \mathrm{C} 18: 1,20.55 \pm 2.62)$ and 3 (C18:0, $31.16 \pm 1.54 ; \mathrm{C} 18: 1,21.67 \pm 1.25)$.

C18:2 showed a tendancy to decrease (fig. 7) : maximum values (p. 100 of total FA) in phase $1(25.05 \pm 3.14)$, decreasing in phase $2(21.92 \pm 3.27)$, and tending to stabilize at the control level in phase $3(19.86 \pm 2.89)$.

3. Fatty acid composition of the cholestery/ esters. - The values (p. 100 of total FA) obtained for the control group were: C14:0, $0.95 \pm 0.42 ; \mathrm{C} 16: 0$, $12.89 \pm 1.72 ; \mathrm{C} 16: 1,5.79 \pm 1.03 ; \mathrm{C} 18: 0,3.33 \pm 0.55 ; \mathrm{C} 18: 1,35.23 \pm 4.26$; $\mathrm{C} 18: 2,39.34 \pm 4.38 ; \mathrm{C} 18: 3,3.23 \pm 0.86$.

In the experimental sheep, myristic $(0.87 \pm 0.27)$, palmitic $(11.88 \pm 1.30)$, palmitoleic $(5.70 \pm 1.08)$ and linolenic acids $(3.28 \pm 0.82)$ remained stable during the experiment. Only stearic, oleic and linoleic acids showed significant changes.

C18:0 showed the following changes ( $p .100$ of total FA) : decreasing values during the first experimental weeks, low values in phase $1(1.93 \pm 0.34)$, increasing values in phase $2(3.14 \pm 0.63)$, stabilized rates in phase $3(4.33 \pm 0.72)$.

As shown in figures 8 and 9, the pattern of changes in C18:1 for all experimental sheep was opposite to that for $\mathrm{C} 18: 2$. For $\mathrm{C} 18: 1$ there were decreasing 


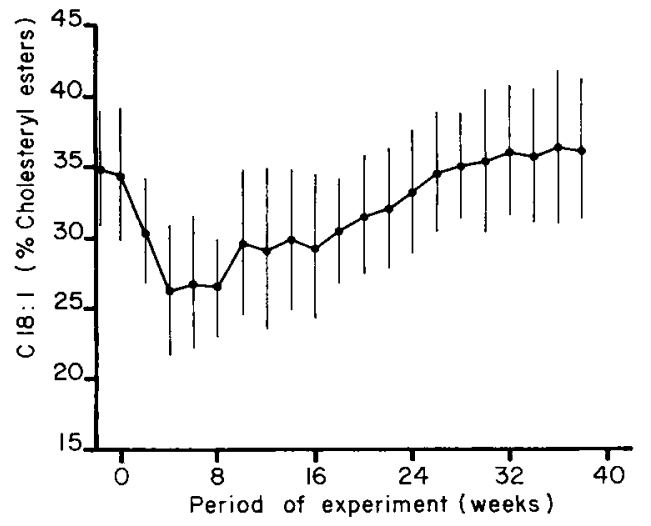

FIG. 8.

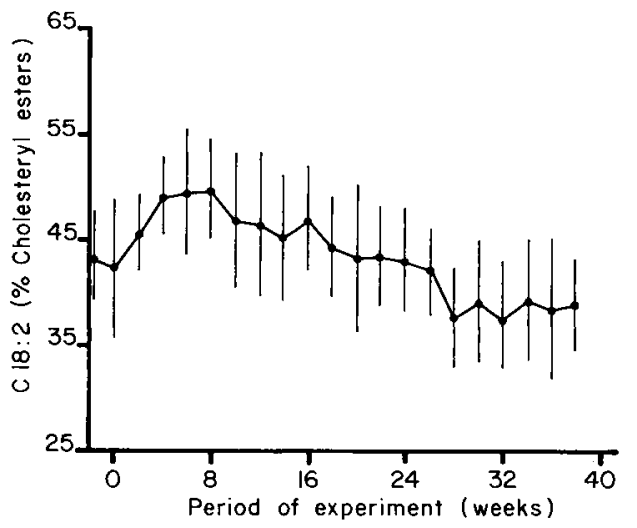

FIG. 9.

FIG. 8. - Changes in oleic acid of plasma cholesterol esters in ad libitum fed sheep. Weeks -2 to 0 correspond to the pre-experimental period and weeks 1-38 to the experimental period.

FIG. 9. - Changes in linoleic acid of plasma cholesterol esters in ad libitum fed sheep. Weeks -2 to 0 correspond to the pre-experimental period and weeks $1-38$ to the experimental period.

values during the first weeks of ad libitum feeding, low values (p. 100 of total $F A)$ in phase $1(27.34 \pm 4.69)$, increasing values in phase $2(31.54 \pm 4.60)$, and identical values for control and ad libitum fed sheep in phase 3 (35.88 \pm 4.83$)$. For $\mathrm{C} 18: 2$, the corresponding values were : phase $1,48.60 \pm 5.23$, phase 2, $43.90 \pm 5.36$ and phase $3,38.49 \pm 5.41$.

4. Fatty acid composition of the triglycerides. - The values obtained for the control group were : C14:0, $1.93 \pm 0.58 ; C 16: 0,26.16 \pm 1.09 ; \mathrm{C} 16: 1$, $5.10 \pm 0.64 ; \mathrm{C} 18: 0,32.32 \pm 9.15 ; \mathrm{C} 18: 1,27.90 \pm 6.24, \mathrm{C} 18: 2,5.10 \pm 2.78$.

In the experimental sheep, values (p. 100 of total FA) for myristic $(1.80 \pm 0.41)$ and palmitic acids $(26.23 \pm 2.09)$ were stable during the experimental period. Palmitoleic acid changed as follows : increasing values during the prephase, variable values among the sheep in phase 1 (5.46 \pm 1.47$)$, decreasing values in phase $2(4.91 \pm 0.90)$ and a trend to stabilization in phase 3 (3.94 \pm 0.85).

Changes in stearic acid are shown in fig. 10. C18:0 reached a minimal value by the beginning of phase $1(29.09 \pm 6.37$ p. 100 of total FA) and during this phase the values increased. In phase 2, the values still increased $(33.44 \pm 5.25$ p. 100 of total FA) and the final phase was characterized by stable C18:0 values.

For oleic acid the mean values (p. 100 of total FA) in the experimental group were : phase 1, $29.45 \pm 5.51$, phase $2,28.00 \pm 3.46$, phase $3,28.23 \pm 6.19$.

The changes in linoleic acid were comparable to those observed in the FFA (fig. 5) : increasing values during the prephase, high but decreasing values in phase 1 (8.19 \pm 5.33 p. 100 of total FA), decrease in phase $2(4.74 \pm 2.09$ p. 100 of total FA), stabilized values in phase $3(3.35 \pm 2.08$ p. 100 of total FA). 


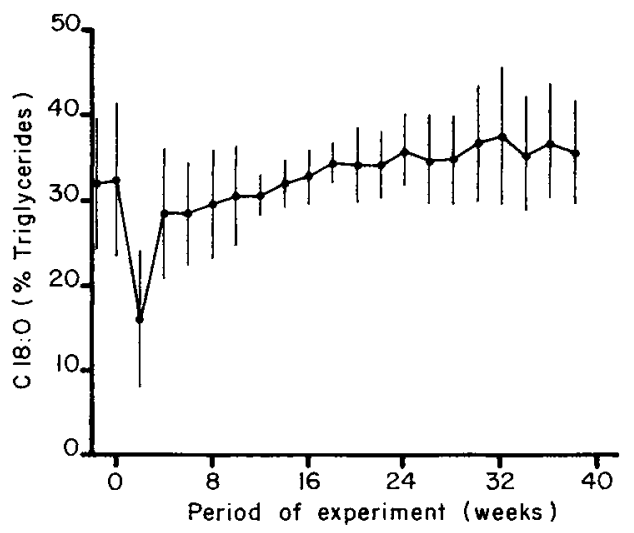

FIG. 10. - Changes in stearic acid of plasma trig/ycerides in ad libitum fed sheep. Weeks -2 to 0 correspond to the pre-experimental period and weeks 1-38 to the experimental period.

Blood glucose concentration. - Blood glucose concentration $(\mathrm{mg} / \mathrm{l}$ of blood) was not altered by ad libitum feeding. Neither the control (general mean : $461 \pm$ 103) nor the experimental (general mean : $478 \pm 115$ ) sheep showed any change.

Blood $\beta$-hydroxybutyrate concentration. - The results obtained for $\beta$ hydroxybutyrate concentration of the experimental sheep appear in figure 11 .

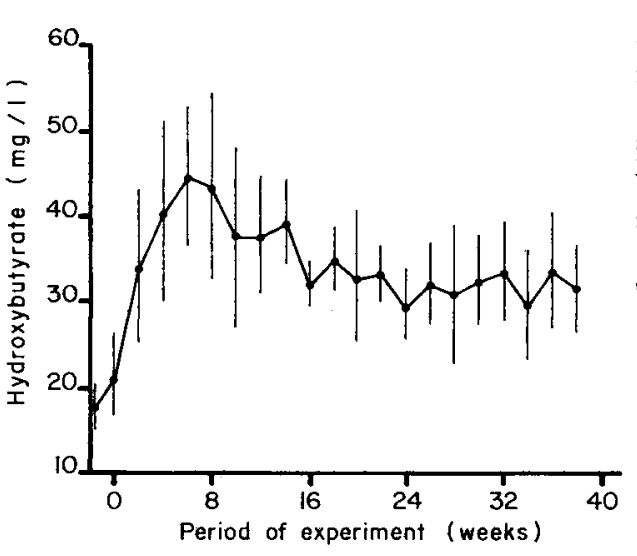

FIG. 11.

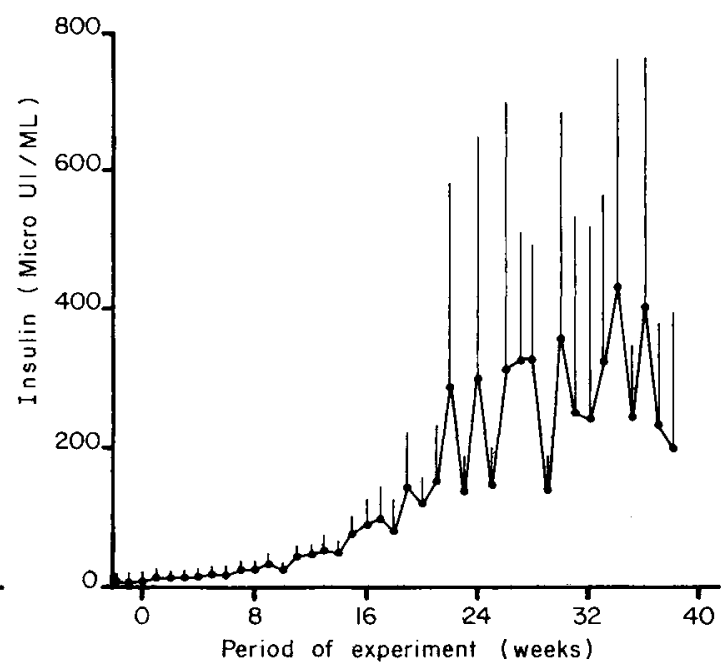

FIG. 12.

FIG. 11. - Blood $\beta$-hydroxybutyrate concentration in ad libitum fed sheep. Weeks -2 to 0 correspond to the pre-experimental period and weeks 1-38 to the experimental period.

FIG. 12. - Plasma insulin concentration in ad libitum fed sheep. Weeks -2 to 0 correspond to the pre-experimental period and weeks $1-38$ to the experimental period. 
During the experiment, values ( $\mathrm{ml} / \mathrm{l}$ of blood) of $\beta$-hydroxybutyrate concentration $(20.05 \pm 4.47)$ were not modified in the control sheep.

In the prephase, when passing from the pre-experimental to the experimental diet, a 2.5-foid increase occurred in the experimental sheep. Stable, high values $(41.50 \pm 9.82)$ were observed in phase 1 . Phase 2 was characterized by a slight decrease $(33.47 \pm 6.65)$. Stable values, at a level 57 p. 100 higher than in the control group $(31.57 \pm 6.22)$, were observed in phase 3 .

Plasma insulin concentration. - During the experiment insulin concentration $(\mu \mathrm{U} / \mathrm{ml}$ of blood) in the control sheep remained stable $(9 \pm 4)$. Results for experimental sheep are shown in figure 12. During the prephase, the concentration $(10 \pm 5)$ was the same as in the control sheep. In phase 1 a progressive increase was observed for all the experimental sheep and the general mean reached a value of $24 \pm 11 \mu \mathrm{U} / \mathrm{ml}$. Phase 2 had a general mean of $152 \pm 230 \mu \mathrm{U} / \mathrm{ml}$ but the values fluctuated between 27 and $1588 \mu \mathrm{U} / \mathrm{ml}$. These fluctuations were still present in phase $3(23-1200 \mu \mathrm{U} / \mathrm{ml})$. The general mean in phase 3 was $297 \pm 340 \mu \mathrm{U} / \mathrm{ml}$.

\section{Discussion.}

It was previously established that a relationship exists between food intake, body weight and body composition during long-term ad libitum feeding of mature sheep (Vandermeerschen-Doizé et al., 1982). The present study was designed to determine whether variations in plasma lipid components, blood glucose, $\beta$-hydroxybutyrate and insulin concentration would respond to changes in body weight and food intake.

Blood lipid distribution, determined by fluorescence quenching, showed only small modifications during the experiment, and the values in the ad libitum fed sheep were close to those of the control group fed a maintenance diet. We also observed previously that this lipid distribution was only slightly influenced by the nature of the food and the intake level (Bouchat et al., 1981), by fasting (Bouchat et al., 1980) and by the time of day (Doizé et al., 1979). Feeding and physiological conditions seemed to have no effect on blood lipid distribution.

Initially, plasma FFA concentrations were lower in the ad libitum fed sheep than in the control group ; this was followed by a gradual increase so that at the end of the experiment, both fat and lean sheep had about the same plasma FFA concentration. This pattern in the ad libitum fed sheep shows that increasing FFA concentration was associated with stable and high body fat content and a decline in food intake. In previous papers (Bouchat et al., $1980 ; 1981$ ) we confirmed the findings of other authors (Günzel and Giesecke, 1974 ; Thompson et al., 1975 ; Thye et al., 1970), demonstrating that fasting induces a rapid increase in the FFA concentration from the first day of fasting and that the concentration tends to stabilize after 5-6 days of fasting. Moreover, this concentration is influenced by the nature and the level of food offered (Bouchat et al., 1981). Plasma FFA concentration is reduced when passing from a roughage to a concentrate diet and is further lowered with increasing level of intake. All these fin- 
dings suggest that complex interrelations exist between plasma FFA concentration and dietary and physiological conditions. In man, Nestel et al. (1978) demonstrated that a reduced plasma FFA clearance in obesity induces an increase in plasma FFA concentration, probably related to impaired esterification in muscle and adipose tissue.

The fatty acid composition of the lipid fractions was comparable with that obtained previously (Bouchat et al., 1980, 1981) and analogous results were reported by Garton (1960) and Lindsay and Leat (1977).

In the present experiment, the change in palmitoleic acid in triglycerides, myristic and palmitic acids in FFA and linoleic acid in cholesteryl esters and phospholipids paralleled the change in voluntary food intake : high values in phase 1 , decreasing values in phase 2 , stable or decreasing values in phase $3 . \mathrm{A}$ similar but less marked relationship was observed for linoleic acid in FFA and triglycerides.

Stearic and oleic acids in FFA, phospholipids and cholesteryl esters in all phases were related to body weight changes. Both fatty acids and body weight showed the same trends: increasing values in phases 1 and 2, stable values in phase 3 . The change was less clear for oleic acid in phospholipids and stearic acid in cholesteryl esters.

The fatty acids of blood lipids, which change in the present study, were the same as those influenced by fasting (Bouchat et al., 1980, 1981) and by the nature of the diet and the level of food given (Bouchat et al., 1981). There is an evident relation between these findings.

Our results are probably related to the observations of Vernon (1977) who studied the effect of dietary palmitoleic, stearic, oleic and linoleic acids on lipogenesis in sheep adipose tissue in vitro. In Vernon's (1977) experiments saturated fatty acids were more effective inhibitors of lipogenesis than polyunsaturated fatty acids : C18:0 was the most effective, followed by C16:1, while C18:1 was the least effective.

There appears to be no information in the literature which can be directly compared with the results reported here, but it may be concluded that feeding adult sheep over extended periods obviously induces changes in the different plasma lipid components. However, furthers studies are required in order to determine whether the variations are the result of decreased food intake or increased body mass.

Changes in the food intake as a result of the fattening state had no effect on blood glucose concentration in the experimental sheep. The values remained very close to those of the control group throughout the test. In previous papers (Bouchat et al., 1980, 1981), we demonstrated that fasting had little influence on glycemia and that the level and the composition of the food had no effect on it. Thus, blood glucose concentration is of less metabolic importance in ruminants than in monogastrics.

In ruminants $\beta$-hydroxybutyrate, deriving from the hepatic metabolism of acetyl CoA and principally from volatile fatty acid transformation in the rumen wall, has an important metabolic function ; during fasting (Bouchat et al., 1980, 1981) and after feeding (Doizé et al., 1979) its blood concentration increases. In 
fasting, more blood fatty acids are taken up by the liver and intensively transformed into ketone bodies. The large increase of blood ketone bodies after feeding originates from the transformation of butyric acid into $\beta$-hydroxybutyrate in the rumen wall. This profile has not yet been investigated during long-term ad libitum feeding. In the present experiment, blood $\beta$-hydroxybutyrate concentration showed a 2-fold increase when passing from the limited intake level to ad libitum feeding. Thereafter, a decrease was observed parallel to changes in voluntary food intake and some fatty acids of blood lipids. Moreover, $\beta$-hydroxybutyrate was opposed to body weight, stearic and other fatty acids.

There is thus an evident relationship between blood $\beta$-hydroxybutyrate concentration, food intake and fattening state in sheep. Further studies are needed to determine if the $\beta$-hydroxybutyrate profile is directly interrelated with changes in voluntary food intake or in body fat level.

During the prephase of the present experiment, both control and experimental sheep achieved the same plasma insulin concentration (about $10 \mu \mathrm{U} / \mathrm{mi}$ ) and no changes were noted when the experimental sheep were given the ad libitum diet. In phase 1, plasma insulin levels rose gradually, and when passing from phase 1 to 3 a 30 -fold increase occurred. Moreover, in phases 2 and 3 marked fluctuations were observed with peaks up to $1600 \mu \mathrm{U} / \mathrm{ml}$, suggesting pulsatile emissions. Fattening and lowered food intake were thus associated with a very high plasma insulin concentration.

The effects of insulin on ad libitum feeding in ruminants under natural conditions over extended periods have received little attention in comparison to the extensive literature concerning short-term feeding control (De Jong, 1979; Kamalu and Trenkle, 1978 ; Nicholson, 1979). An increase of insulinemia occurs directly after feeding and low values are obtained during fasting (Bouchat et al., 1981). Insulin infusion stimulates food intake and depresses plasma glucose concentration (Anika et al., 1980 ; Deetz et al., 1980 a, b ; Panksepp et al., 1975). In our long-term experiment, the high insulin level observed in phase 3 did not alter plasma glucose concentration and was associated with low food intake. This increase of the insulin level might result from a decreased sensitivity of the adipose tissue insulin receptors, demonstrated in rat by Olefsky (1977) and in man by Kolterman et al. (1979). This diminished sensitivity is probably caused by an impairment of fatty acid synthesis in the larger cells, resulting in a decrease of acetyl CoA carboxylase and fatty acid synthetase content (Richardson and Czech, 1979). it should be pointed out that in our experiment the rate of small cells (S1) remained high in the experimental sheep. From the literature and our results, we conclude that complex interrelationships may exist between voluntary food intake and blood insulin concentration, depending on the fattening state. Further experiments are necessary to clarify these interrelationships.

Reçu en avril 1982,

Accepté en août 1982.

Acknowledgements. - The authors would like to thank Dr. Schifflers of the Facultés Universitaires Notre-Dame de la Paix for his generous help with the statistical analysis. This 
work was supported by the Institut pour I'Encouragement de la Recherche Scientifique dans I'Industrie and I'Agriculture (IRSIA), rue de Crayer, B-1050 Brussels, Belgium.

Résumé. Effets à long terme d'une distribution illimitée d'aliments sur les lipides plasmatiques et sur les concentrations en glucose, en $\beta$-hydroxybutyrate et en insuline du sang de mouton adulte.

En vue d'étudier les variations à long terme des lipides plasmatiques, de la glycémie, de la concentration sanguine en $\beta$-hydroxybutyrate et de l'insulinémie, des brebis Suffolk adultes ont été nourries à volonté pendant 8 mois et comparées à des brebis témoins recevant une ration couvrant les besoins énergétiques d'entretien.

La distribution des lipides plasmatiques n'est que faiblement influencée par le niveau d'ingestion et l'état d'engraissement.

Une distribution illimitée de concentrés provoque une diminution de la concentration plasmatique en AGL. Lorsqu'en fin d'engraissement, le niveau d'ingestion volontaire diminue, une augmentation progressive de cette concentration est observée. Certains acides gras composant les différentes fractions lipidiques varient en cours d'expérience. Quand le niveau d'ingestion volontaire diminue, les proportions $d$ 'acides myristique et palmitique dans les $A G L, d$ acide palmitoléique dans les triglycérides et d'acide linoléique dans les autres fractions lipidiques diminuent. Au contraire, les acides stéarique et oléique des AGL, des phospholipides et des esters de cholestérol augmentent. Tous ces acides montrent des valeurs stables lorsque le niveau d'ingestion et la composition corporelle se sont stabilisés.

La glycémie n'évolue pas en cours d'expérience. Au cours de la première phase $d^{\prime}$ engraissement, la concentration en $\beta$-hydroxybutyrate est stable chez les animaux nourris à volonté et atteint un niveau 2 fois plus élevé que chez les témoins. Elle diminue au cours de la seconde phase et se stabilise à nouveau pendant la dernière phase. Elle dépasse alors de 50 p. 100 celle mesurée chez les témoins.

Au cours des 6 premières semaines d'ingestion ad libitum, les moutons expérimentaux présentent la même concentration plasmatique d'insuline que chez les témoins. Par la suite, cette concentration augmente jusqu'à 30 fois chez les expérimentaux et montre une très grande variabilité ( 20 à $1600 \mu \mathrm{U} / \mathrm{ml}$ ).

Cette expérience montre que chez des moutons adultes nourris à volonté, des interrelations complexes existent entre les évolutions d'une part des ingestions volontaires d'aliments et de l'état d'engraissement, d'autre part de diverses substances sanguines. Des recherches ultérieures sont nécessaires pour clarifier ces interrelations.

\section{Références}

ANIKA S. M., HOUPT T. R., HOUPT K. A., 1980. Insulin as a satiety hormone. Physiol. Behav., 25, 21-23.

BOUCHAT J. C., DOIZÉ F., PAQUAY R., 1980. Effects of fasting on blood composition and nitrogen losses in the adult sheep depending on previous diet and body weight. Reprod. Nutr. Dévelop., 20, 77-92.

BOUCHAT J. C., DOIZÉ F., PAQUAY R., 1981. Influence of diet and prolonged fasting on blood lipids, ketone bodies, glucose and insulin in adult sheep. Reprod. Nutr. Dévelop., 21, 6, 69-81.

CHRISTOPHE A., MATTHIJS F., 1966. New method for the determination of the fatty acid pattern of serum lipid classes. Clin. chim. Acta, 16, 39-43.

DEETZ L. E., WANGSNESS P. J., 1980. Effect of intrajugular administration of insulin on feed intake, plasma glucose and plasma insulin of sheep. J. Nutr., 110, 1976-1982.

DEETZ L. E., WANGSNESS P. J., KAVANAUGH J. F., GRIEL L. C., 1980. Effect of intraportal and continuous intrajugular administration of insulin of feeding in sheep. J. Nutr., 110, 19831991. 
DE JONG A., 1979. Regulation of insulin and glucagon secretion in goat. Ann. Rech. vétér., 10, 240-243.

DOIZE F., BOUCHAT J. C., PAQUAY R., 1979. Diurnal changes in blood ketone bodies, glucose and lipids according to the energy intake in adult sheep. Ann. Biol. anim. Bioch. Biophys., 19, 393-404.

GARTON G. A., 1960. Lipid metabolism in herbivorous animals. Nutr. Abstr. Rev., 30, 1-16.

GÜNZEL R., GIESECKE D., 1974. The influence of feeding, fasting and phloridzin diabetes on the relationship between free fatty acids and glucose in the blood of sheep. Zbl. vet. Med. A, 21, 279-284.

KAMALU T. M., TRENKLE A. H., 1978. Insulin secretory response to increasing doses of glucose and volatile fatty acids in sheep. Nutr. Rep. Int., 18, 267-271.

KENNEDY G. C., 1950. The hypothalamic control of food intake in rats. Proc. roy. Soc. London, 137, 535-549.

KOLTERMAN O. G., REAVEN G. M., OLEFSKY J. M., 1979. Relationship between in vivo insulin resistance and decreased insulin receptors in obese man. J. clin. Endocrinol. Met., 48, 487-494.

OLEFSKY J. M., 1977. Insensitivity of large rat adipocytes to the antilipolytic effects of insulin. J. Lipid Res., 18, 459-464.

RICHARDSON D. K., CZECH M. P., 1979. Diminished activities of fatty acid synthesis enzymes in insulin-resistant adipocytes from spontaneously obese rats. Horm. Metab. Res., 11, 427-431.

LINDSAY D. B., LEAT W. M. F., 1977. Oxidation and metabolism of linoleic acid in fed and fasted sheep. J. agric. Sci. Lamb. Camb., 89, 215-221.

MORGAN C. R., LAZAROW A., 1963. Immunoassay of insulin : two-antibody system. Plasma insulin levels of normal, subdiabetic and diabetic rats. Diabetes, 12, 115-126.

NESTEL P. J., ISHIKAWA T., GOLDRICK R. B., 1978. Diminished plasma free fatty acid clearance in obese subjects. Metabolism, 27, 589-597.

NICHOLSON T., 1979. Some effects of insulin on eating and rumination. Ann. Rech. véter., 10. 231-232.

PANKSEPP J., POLLACK A., KROST K., MEEKER R., RITTER M., 1975. Feeding in response to repeated protamine zinc insulin injections. Physiol. Behav., 14, 487-493.

THOMPSON G. E., GARDNER J. W., BELL A. W., 1975. The oxygen consumption, fatty acid and glycerol uptake of the liver in fed and fasted sheep during cold exposure. Quart. $J$. exp. Physiol., 60, 107-121.

THYE F. W., WARNER R. G., MILLER P. D., 1970. Relationship of various blood metabolites to voluntary feed intake in lactaring ewes. J. Nutr., 100, 565-572.

VANDERMEERSCHEN-DOIZÉ F., BOUCKOMS-VANDERMEIR M. A., PAQUAY R., 1982. Effects of long-term ad libitum feeding on the voluntary food intake, body weight, body composition and adipose tissue morphology of lean adult sheep. Reprod. Nutr. Dévelop., 22, 10491060.

VERNON, R. G., 1977. Effect of different fatty acids on lipogenesis in rat and sheep adipose tissue in vitro. Int. J. Biochem., 8, 517-523. 